Volume 5 Issue 2, July 2021

sisaddergi@gmail.com

Makale Türü/Article Type: Araştırma/Research

Makale Gönderim Tarihi/Received Date: 19.03.2021

Makale Kabul Tarihi/Accepted Date: 17.04.2021

DOI: $10.30692 /$ sisad.899502

\title{
AZERBAYCAN'DA GİRIŞIMCILIKK FAALIYETININ MEVCUT DURUMU VE GELIŞME YÖNLERI
}

\author{
Current State of Entrepreneurial Activity and Development Directions in Azerbaijan \\ Jamal HAJIYYV
}

Doç. Dr.

Azerbaycan Turizm ve Menecment Üniversitesi

Ekonomi Bölümü

ORCID ID: 0000-0002-6409-3010

jamalhajiyev@yandex.ru

Vasif AHADOV

Prof. Dr.

Azerbaycan Turizm ve Menecment Üniversitesi

Ekonomi Bölümü Doktora Öğrencisi

ORCID ID: 0000-0003-0003-8933

vasifahad@gmail.com

Atıf/Citation: Jemal Hajiyev, Vasif Ahadov (2021), "Azerbaycan'da Girișimcilik Faaliyetinin Mevcut Durumu ve Gelişme Yönleri”, Stratejik ve Sosyal Araştırmalar Dergisi, C.5, S.2 Temmuz 2021 s.181-193.

Öz: Modern zamanlarda girişimciliğin oluşumu ve gelişimi tüm dünya için olduğu kadar Azerbaycan Cumhuriyeti için de önemlidir. Özellikle, 2008 küresel mali krizinin ardından petrol sektöründe yaşanan gerileme, petrol dışı sektörün ve parçası olduğu ticari faaliyetlerin gelişimine ivme kazandırmıştır. Batılı ülkelerin deneyimleri, ekonomik kalkınmanın küçük ve orta ölçekli işletmelerin genişlemesi sonucunda tesis edilebileceğini göstermektedir.

Azerbaycan'da petrol dışı sektörün gelişmesi için girişimciliğin geliştirilmesi önemli koşullardan biridir. Bu nedenle hem bölgelerde, hem de şehirlerde bu alanın gelişmesini sağlamak devletin karşı karşıya olduğu temel görevlerden biridir. Girişimciliği canlandırmak, girişimcileri desteklemek, var olan ve olası sorunlarını gidermek için yapılan çalışmalara rağmen girişimcilik alanında hala sorunlar var. Bu veya diğer sorunlar petrol dışı sektörün gelişimini yavaşlattığı için bu durum her zaman devletin odak noktasıdır. Bu nedenle, hem bölgelerdeki, hem de şehirlerdeki girişimciliğin kalkınma yönleri konusu bugün hala geçerlidir.

Bu bağlamda, makale Azerbaycan'daki mevcut girişimciliğin durumunu, sosyal ve ekonomik gelişme eğilimlerini ve bunun yanı sıra sosyal verimliliğini artırmak için ekonomik ve örgütsel önlemleri inceliyor ve analiz ediyor. 
Anahtar Kelimeler: girişimci, girişimci faaliyet, girişimcilere devlet desteği, girişimcilik geliştirme

\begin{abstract}
The formation and development of entrepreneurship in modern times is important for the Republic of Azerbaijan as well as for the whole world. Especially, the decline in the oil sector after the 2008 global financial crisis has accelerated the development of the non-oil sector and the commercial activities of which it is a part and medium sized enterprises can be established as a result of the expansion.
\end{abstract}

Development of entrepreneurship is one of the important conditions for the development of the non-oil sector in Azerbaijan. For this reason, it is one of the main tasks faced by the state to ensure the development of this area in both regions and cities. Despite the efforts to revive entrepreneurship, support entrepreneurs, and solve existing and potential problems, there are still problems in the field of entrepreneurship.

The root cause of these problems is that Soviet ideology still remains in people's minds and thoughts. Entrepreneurs living with this ideology do not accept innovation, new technology or foreign experience. Entrepreneurs who have built their business extensively are reluctant to build their business on a dense basis and believe that if they set up their business in this direction, they will suffer rather than profit.

This is always the focus of the state, as these or other problems slow down the development of the non-oil sector. Therefore, the issue of development aspects of entrepreneurship in both regions and cities is still relevant today.

In this context, the article examines and analyzes the current state of entrepreneurship, social and economic development trends in Azerbaijan, as well as economic and organizational measures to increase social efficiency.

Keywords: entrepreneur, entrepreneurial activity, state support to entrepreneurs, entrepreneurship development

\title{
GíRiş
}

Ülkede piyasa ekonomisine geçişle bağlantılı olarak uygulanan ekonomik reformlar sonucunda, nüfusun ticari faaliyeti için elverişli koşulların yaratılması nihayetinde engirişimciliğin ortaya çıkmasına ve oluşumuna yol açmıştır. Bir piyasa ekonomisinde, insanın doğasında bulunan bağımsız, ekonomik ve ticari faaliyet, girişimcilik faaliyetinde kendini gösterir. Sosyal ve ekonomik kalkınmanın temel koşulu, çeşitli biçimler ve içerikler alan girişimcilik faaliyetidir. Girişimciler ise proaktif, bilimsel yenilikleri benimseyen ve uygulayan toplumun sosyal katmanlarını oluşturur.

Azerbaycan Cumhuriyeti'nde girişimcilik faaliyetinin gelişimi, ekonomik kalkınma kavramlarına göre lider konumdadır ve hem üretim, hem tüketim hem de dağıtım ilişkilerinin sağlanmasında ekonomik-organizasyonel bir mekanizma rolü oynamaktadır. Bu nedenle Azerbaycan modeline göre girişimciliğin gelişimi, ülke ekonomisinin mevcut durumunu, bu alanda perspektif gelişiminin oluşumunu ve üretici güçlerde iyileştirmelerin uygulanmasını kapsamaktadır.

Bağımsız Azerbaycan Cumhuriyeti, piyasa ilişkileri koşullarında girişimcilik faaliyetinin gelişmesi için, serbest girişimcilik faaliyetinin kurulmasına özel önem vermektedir. Ulusal ekonominin gelişmesi, nüfusun ihtiyaçlarına ve ülkedeki rekabetçi pazara adaptasyon, insanlarda girişimcilik ruhunun eğitilmesi ve girişimcilik faaliyetinin gelişme yönünün belirlenmesinde gerekli yardımı sağlar.

Serbest girişimcilik faaliyetinin oluşumu, ülkedeki mal üretimini arttırır, tüketici pazarının gelişmesi için koşullar yaratır, işsizliğin ortadan kaldırılmasına, istihdamın sağlanmasına ve devlet gelirlerinin artmasına yardımcı olur.

\section{Araştırmanın amacı}

Azerbaycan'da girişimciliğin gelişiminin özellikleri, girişimcilik faaliyetlerinin sonuçlarının incelenmesi ve perspektif yönleri. 


\section{Araştırmanın Teorik ve Metodolojik Temelleri}

Girişimcilik alanında yazılan yabancı literatür, bilimsel araştırmalar, klasik ve Azerbaycanlı bilim adamlarının bu alanın mevcut durumu ve gelişsimi ile ilgili çalışmaları ve görüşleri. Azerbaycan'da girişimciliğin gelişmesi ve oluşumu ile ilgili yasal düzenlemelerin kabulü, özellikle anayasa yasaları ve bu yönde önlemlerin uygulanması, çalışmanın temel teorik ve metodolojik yönlerini kapsamaktadır. Ayrıca girişimciliğin gelişimini belirlemek için istatistiksel göstergeler kullanılmıştır.

\section{Çalışmanın Temel Amaç ve Hedefleri}

Makalenin temel amacı, Azerbaycan'daki girişimciliğin piyasa ekonomisindeki mevcut durumunu, sosyo-ekonomik gelişme eğilimlerini incelemek ve bu doğrultuda belirlenen görevleri yerine getirmektir.

\section{Araştırma Veritabanı}

Mevcut literatür, monografiler, internet kaynakları, Azerbaycan Cumhuriyeti Devlet İstatistik Komitesi raporları ve istatistikleri, Ekonomi ve Maliye Bakanlıklarının materyalleri, Cumhurbaşkanlığ kararnameleri, girişimcilik mevzuatı ve Azerbaycan Cumhuriyeti Anayasası kullanılmıştır.

\section{Araştırmanın Bilimsel Yeniliği}

Araştırmanın bilimsel yenilikleri şu alanlarda yorumlanabilir:

- Azerbaycan Cumhuriyetinde girişimciliğin bilimsel temelini analiz ederek gelişme ve oluşum yasaları hakkında önerilerde bulunmak;

- Girişimcilik faaliyetinin ekonomik verimliliğini belirlemek için bir gösterge sistemi sağlamak;

- Bu araştırma sayesinde, girişimciliğin mevcut durumunu incelemek ve ekonomik sonuçlarının gerçek göstergelerini göstermek gerekiyor.

\section{Yöntem}

Bir tür ekonomik faaliyet olarak girişimciliğin tarihi Orta Çağ'a kadar uzanmaktadır. Zaten tüccarlar, tüccarlar, zanaatkârlar ve hayırsever misyonerler bu tür girişimciliğe girişmeye başlamıştır.

Girişimciliğin teorik temelleri A.Smith, R.Cantillon, Tunen, K.Marks, Y.Sumpeter ve diğerleri gibi dünya ekonomistleri tarafından incelenmiştir. Modern zamanlarda, Azerbaycan'da bu alanın çalışmasında teorik ve pratik konularla ilgili A.B.Abbasov, G.N.Manafov, S.H.Muradov, A.S. Imanov, Z.A. Samadzade, A.F. Musayev, I.Z. Seyfullayev, V.M. Niftullayev, Y.A. Kalbiyev ve diğer iktisatçılar vergiler açısından girişimcilik çalışmalarına katkıda bulundular. Küçük ve orta ölçekli işletmelerin oluşumu ve geliştirilmesi sorunları R.M.Jabiyev, T.N. Aliyev, N.O. Hajiyev, A.S. Mehtiyev, A.B.Sariyev, F.H. Abbasov ve diğerleri tarafindan araştırılmıştır.

1990'larda sosyalist sistemin çöküşü girişimcilik için koşullar yarattı.Bağımsız cumhuriyetimizde mülkiyet ve girişimcilik faaliyetleriyle ilgili alınan kararlar, bu tür faaliyetler için yasal bir temel oluşturmuştur. Bu dönemden itibaren, özel mülkiyet ve girişimcilik faaliyeti, anonim şirketlerin ve diğer ekonomik faaliyet biçimlerinin ortaya çıkmasıyla yeni bir biçim ve içerik aldı. 
Azerbaycan'da bağımsızlık kazandıktan sonra girişimciliğin gelişimi aşağıdaki aşamalara ayrilabilir:

1993'e kadar olan dönem

1993-2003 y1l

2003-2015 y1l

2015 sonras 1

12 Ekim 1992'de Azerbaycan Cumhuriyeti Ulusal Girişimcilik Destekleme Fonu Statüsü'nün onayı ile girişimcilere öncelikli kredi sağlayan ilk finans kurumu kuruldu. 5 Aralık 1992'de, ülkedeki girişimcilik faaliyetlerinin yasal ve ekonomik düzenlemesini sağlayan Azerbaycan Cumhuriyeti "Girişimcilik Faaliyetleri Hakkında Kanun" onaylandı.

Ulusal lider Haydar Aliyev'in değerli bir halefi olan İlham Aliyev'in 2003 yllında iktidara gelmesinden sonra, bölgelerdeki girişimcilik faaliyetlerinin geliştirilmesi bir devlet önceliği haline geldi ve 2004'ten beri birbirini izleyen devlet programları (2004-2008, 2009-2013, 20142018, 2019-2023 yıllar bölgelerde sosyo-ekonomik kalkınma için eyalet programları), bölgelerde girişimciliğin gelişmesine büyük bir ivme kazandırmıştır. Sonuç olarak 2019 yılında Tarım Bakanlığı'na bağlı Tarım Kredi ve Kalkınma Ajansı Girişimciliği Geliştirme Fonu'nun düşük faizli işletmelere sağladığ 100 milyon manattan fazla kredinin çoğu bölgelere düştü. Bu fonların bölgelere göre dağılımı aşağıdaki diyagramda gösterilmektedir:

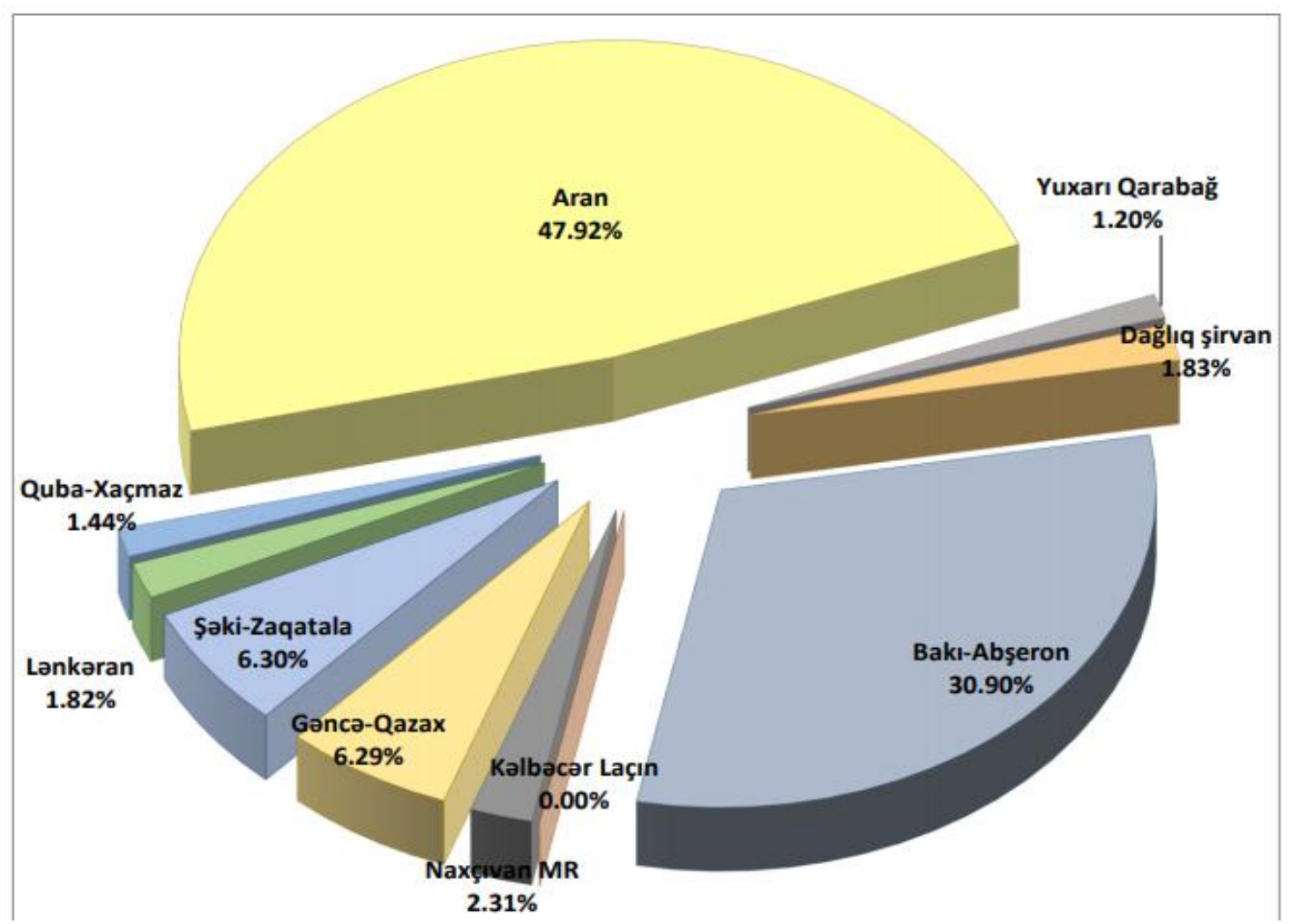


2015 yılı sonrasında girişimcilik alanında Stratejik Yol Haritaları ve Devlet Programları kabul edildi. Azerbaycan Cumhuriyeti Cumhurbaşkanı'nın 6 Aralık 2016 tarih ve 1138 sayılı Kararı ile ülke ekonomisine yönelik 11 ekonominin dahil olmak üzere 12 Stratejik Yol Haritası onaylandı. Bu belgelerden biri olan "Azerbaycan Cumhuriyetinde küçük ve orta ölçekli işletmeler düzeyinde tüketim mallarının üretimi için Stratejik Yol Haritası", özellikle ülkedeki küçük ve orta ölçekli işletmelerin (KOBİ'ler) durumunu analiz ederek ayrıntılı bilgi sağlar.

Yol haritas1, 2020 y1lına kadar stratejik vizyonu, 2025'e kadar olan uzun vadeli vizyonu ve 2025 sonrası için hedef vizyonu kapsıyor. Yol haritası, yukarıda özetlenen görüşlerde ana hatlarıyla belirtilen hedeflere ulaşmak için 5 stratejik hedef belirler. Bu stratejik hedefler arasında, küçük ve orta ölçekli işletmeler faaliyetleri için iş ortamının ve düzenleyici çerçevenin iyileştirilmesi, onların finansal kaynaklara verimli ve etkili erişiminin sağlanması, uluslararasılaşması ve diş pazarlara erişimin artırılması vb. yer almaktadır. Her hedef için öncelikler, gerekçeleri ve bunların uygulanmasını sağlamak için alınacak önlemler dahildir. Stratejik hedeflere ulaşılmasını sağlayacak bir eylem planı da onaylandı.

Azerbaycan Cumhuriyeti Cumhurbaşkanı Sayın İlham Aliyev tarafından başarıyla uygulanan ekonomik kalkınma politikasının ana yönlerinden biri özel sektörün kapsamlı desteğidir. Daha da genişlemesi için uygun bir ortam yaratmakdır. 31 Temmuz 2018 tarihli Cumhurbaşkanlığı Kararnamesi'ne göre, Ulusal Girişimcilik Destek Fonu kaldırılmış, Ekonomi Bakanlığı bünyesinde kamu tüzel kişiliği olarak Girişimciliği Geliştirme Fonu kurulmuştur. Böylece Kurallara göre, Fondan işletmelere açılacak küçük kredilerin limiti 50.000 manat, orta büyüklükteki kredilerin limiti 1 milyon manat ve büyük kredilerin limiti 10 milyon manat olarak belirlenmiştir. Küçük, orta ve büyük kredilerin vadelerinin sırasıyla 3 (üç), 5 (beş) ve 10 (on) yıllı, kredi kullanım ödemesiz dönemini, ilk 1/2 dönemini kapsayacağı kaydedildi.

Ekonomi Bakanlığı tarafından işletmeler için finansal kaynaklara erişimin kolaylaştırılması, kredi başvurularının kısa sürede işleme alınması, gerekli analizlerin kredi kuruluşları ve Girişimcilik Geliştirme Fonu tarafından yapılması ve kararların girişimcilere iletilmesi gibi süreçler, geliştirdiği ve uyguladığı e-Kredi Platformu üzerinden gerçekleştirilmektedir. Ticari işletmenin başvurusu, hızlı bir kredi için 7 iş günü içinde (200.000 manat'a kadar) ve geleneksel bir kredi için (200.000 manat üzerinde) 10 iş günü içinde değerlendirilir. Pandemiden faaliyet alanı etkilenen bir işletmenin başvurusu reddedilirse, girişimci neden olarak belirtilen eksiklikleri giderdikten sonra bu veya başka bir yetkili banka aracılığıyla yeniden başvuru yapma hakkına sahiptir.

$\mathrm{Bu}$ elektronik sistem aracılığıyla işletme kredilerinin verilmesi, girişimciler için bir dizi avantaj yaratmaktadır. Girişimciler online olarak işletme kredisi başvurusu yapar, başvuruları yetkili kredi kuruluşları ve Ekonomi Bakanlığı tarafından eş zamanlı olarak değerlendirilir ve başvuruların durumu anlık olarak izlenir.

Elektronik Kredi Platformunun hayata geçirilmesi aynı zamanda kredi temininde esneklik ve şeffaflık, girişimciler için eşit koşullar sağlayacak, sağlıklı bir rekabet ortamı yaratacak, girişimciler için krediye erişimi genişletecek, zaman ve paradan tasarruf sağlayacaktır. Azerbaycan Cumhuriyeti Cumhurbaşkanı, 19 Mart 2020 tarihinde "Koronavirüs (COVID-19) salgınının olumsuz etkisinin ve dolayısıyla dünya enerji ve borsalarında Azerbaycan Cumhuriyeti ekonomisindeki keskin dalgalanmaların azaltılması"na ilişkin bir kararname imzaladı ve bu sıraya göre yapılacak çalışmaların üç aşamada uygulamaya geçirilmesi hedefleniyor. İlk aşamada, pandemiden etkilenen bölgelerdeki çalışanların maaşlarının bir kısmının ödenmesi, bireysel (mikro) girişimcilere maddi destek sağlanması ve ekonomik faaliyeti korumak için vergi teşviklerinin sağlanması planlanmaktadır. 
Pandemiden etkilenen bölgelerdeki işçi sayısının azalmasını önlemek için iş sözleşmesi bazında çalışan 300 min işçinin (iş sözleşmeli) maaşlarının belirli bir kısmının ödeme mekanizması devlet tarafından ödemeleri sağlanmaktadır ve girişimçilere 215 milyon manat tutarında mali destek sağlandı. (J. Hajiyev, 2021, s.4)

Girişimciliğin gelişmesine yönelik sistematik ve tutarlı devlet desteğinin bir başka örneği de "eticaret" portalıdır. 25 Ağustos 2008 tarihli kararla Azerbaycan'da "e-ticaret" alanındaki çalışmaların yoğunlaştırılması üzerine Azerbaycan Cumhuriyeti Cumhurbaşkanı Ekonomik Kalkınma Bakanlığı'na talimat verdi. Görevin uygulanmasını sağlamak için Ekonomi ve Sanayi Bakanlığ 1 , başta tarımsal üreticiler olmak üzere girişimcilerin serbest pazara erişimini desteklemek için "e-ticaret" konusunda bir web portalı oluşturmuştur. Portal, B2B (işletmeden işletmeye) modeline dayalı Azerbaycan'daki ilk e-ticaret portalıdır. Amaç, yerel alıcılara yerel işletmeler, ürünleri ve hizmetleri hakkında bilgi sağlayarak iş ilişkilerinin kurulmasını desteklemek ve pazarlara ücretsiz erişim sağlamaktır.

Modern elektronik bilgi alı̧sverişi teknolojilerine dayanan "e-ticaret" portalı, girişimcilerin ürettikleri ürün (hizmetler hakkında ilgili taraflara bilgi vermesine ve ürün), hizmet alıcilarının ihtiyaçları hakkında bilgi almalarına olanak tanır. E-ticaret portalı, kullanıcılara satış bilgileri desteği de sağlar.

Azerbaycan İhracat ve Yatırımı Geliştirme Vakfı ülkedeki girişimcilerin ihracat potansiyelini artırma, yatırım fursatlarını genişletme, potansiyel ortaklar bulma ve ortak işbirliği projelerini hayata geçirme konularında girişimcileri yakından desteklemektedir. Fonun ülkemizde düzenlediği iş forumları, yerli işadamlarının tanıtılması, yurt dışı pazarlara ürün lansmanı, iş anlaşmaları imzalanması ve yurt dışı iş ilişsilerinin geliştirilmesi açısından önemli rol oynuyor. Hem yabancı yatırımcılar, hem de yerli üreticiler, AZPROMO'nun hem Azerbaycan'da iş kurmak, aynı zamanda dış pazarlara girmek için sunduğu hukuki danışmanlık hizmetinden yararlanabilirler.

Hükümet, ülke ekonomisine yatırım çekmek için "açık kapı" politikası izliyor. Şu anda, Azerbaycan Hükümeti ülkedeki ekonomik reformları sürdürmek, iş ortamını daha da iyileştirmek ve petrol dışı sektörü geliştirmek için önlemler alıyor.

Azerbaycan Cumhuriyeti Cumhurbaşkanının Özel izin (ruhsat) gerektiren ticari faaliyet türlerinin sayısının azaltılması, özel izinlerin (ruhsatların) verilmesi ve şeffaflığın sağlanması için prosedürlerin basitleştirilmesi hakkında " 19 Ekim 2015 tarih ve 650 sayılı Kararnamesine göre girişimcilere lisansların ASAN hizmet merkezleri aracılığıyla vermeye başladı. Ayrıca 21 Aralık 2015 tarih ve 713 sayılı Cumhurbaşkanlığı Kararnamesi ile ruhsat gerektiren faaliyet sayısı 59 'dan 37'ye indirilmiş, teslimat süresi 15 iş gününden 10 iş gününe düşürülmüştür, ihraç prosedürleri basitleştirildi.

Girişimciliği Geliştirme Fonu, 2020 yılında yetkili kredi kuruluşları aracılığıyla 397 milyon AZN değerinde 908 yatırım projesini finanse etmeleri için girişimcilere 126,9 milyon AZN indirimli kredi sağlamıştır. Bu krediler 2.700'den fazla yeni iş yarattı. Kredilerin\% 57'si tarım sektörünün geliştirilmesine (üretim ve işleme), \%43'ü sanayi ürünlerinin üretim ve işlenmesine ve diğer alanlara yönlendirilmiştir. Verilen kredilerin \%79'u bölgelere, \%21'i Bakü yerleşim yerlerine düşüyor. İndirimli kredi alanların \% 99'undan fazlası mikro, küçük ve orta ölçekli işletmelerdir ve \%1'den azı büyük işletmelerdi. Pandemiden etkilenen bölgelerde faaliyet gösteren girişimcileri desteklemek için geçen yıl haziran ayında iki program başlatıldı - kredi garantileri ve faiz oranı sübvansiyonları. 
Ülkede ilk kez Ekonomi Bakanlığı'nın dijital bir kredi platformu oluşturduğu ve girişimcilerin kredi garanti mekanizması kapsamında yeni işletme kredileri için online başvuru almaları için başlattığı kaydedildi. 2020 yılında 949 milyon manat değerinde 3.300'den fazla yeni işletme kredisi başvurusu bu platform üzerinden kayıt altına alınmıştır. 148 milyon manat kredi ihtiyacı olan kredilerin 433'ü $(\% 81,9)$ vakıf garantilidir. Aynı zamanda 01.01.2021 tarihine kadar Fona tek seferlik komisyon ödenmiş olup, yürürlüğe giren başvurulardaki kredi tutarı 130 milyon manat, garanti tutarı 74,8 milyon manat olmuştur. Bir diğer destek mekanizması ise, 50 milyon manatı devlet bütçesinden, 50 milyon manatı ise Fondan sağlanan 1 milyar manat kredi portföyüne 100 milyon manat faiz sübvansiyonu sağlamaktır.

2019 yılında Azerbaycan Cumhuriyeti Bakanlar Kurulu'nun ilgili kararı mikro, küçük, orta ve büyük ölçekli işletmelerin dağıtım kriterlerini onayladı.

\begin{tabular}{|l|c|c|}
\hline $\begin{array}{c}\text { Ticari varlıkların boyutuna } \\
\text { göre kategoriler }\end{array}$ & $\begin{array}{c}\text { Ortalama çalışan sayıs1 } \\
\text { (insanlar) }\end{array}$ & $\begin{array}{c}\text { Y1llık gelir (ig) } \\
\text { (min. manat) }\end{array}$ \\
\hline Mikro girişimcilik & $1-10$ & Ig $\leq 200$ \\
\hline Küçük iş & $11-50$ & $200<$ ig $\leq 3000$ \\
\hline Orta ölçekli işletme & $51-250$ & $3000<$ ig $\leq 30000$ \\
\hline Büyük işletme & 251 ve üstü & $30000<$ ig \\
\hline
\end{tabular}

Bu kriterlere göre yıllık geliri 200.000 manat'a kadar çıkan ve maksimum 10 çalışanı olan mikro girişimciler, yıllık geliri 200 binden 3 milyon manata, 11-50 çalışanı olanlar küçük girişimciler, 3 milyondan 30 milyon manat'a kadar yıllık gelir, 51-250 çalışanı olanlar orta ölçekli işletmelerdir, yıllık geliri 30 milyondan fazla ve 250 'den fazla çalışanı olanlar büyük girişimci olarak kabul edilecektir. Aynı zamanda girişimcilerin mikro, küçük, orta veya büyük girişimci olarak tanımlanması, "ortalama çalışan sayısı" ve "yıllık gelir" kriterlerinin daha yüksek olmasına dayanmaktadir.

Böyle bir ayrım tüm dünyada mevcuttur ve vergi indirimlerinin uygulanması içindir. Ancak Azerbaycan'da hem devlet bütçesinden, hem de Vergi Bakanlığından sağlanan çeşitli faydaların kapsamını belirlemek için bu listeye mikro işletmeler eklenmiştir. Aynı zamanda, Vergi Kanununda yapılan değişiklikler mikro işletmeleri belirtmekte ve vergilendirilmelerine ilişkin belirli hükümler içermektedir. Bu, vergilendirilebilir işletmelerin farklılaşmasına izin verecektir.

Bütün bunların mantıksal sonucu, bugün Azerbaycan'daki girişimciliğin gelişmişlik düzeyi açısından gelişmiş ülkelerin gerisinde kalmaması ve BDT ülkeleri arasında ilk sıralarda yer almasıdır. Aşağıdaki tablo, 2019 yılında Azerbaycan'daki mikro, küçük ve orta ölçekli işletmelerin temel makroekonomik göstergelerini göstermektedir. 
Tablo 1. Mikro, küçük ve orta ölçekli işletmelerin temel makroekonomik göstergeleri

\begin{tabular}{|l|l|l|l|l|}
\hline \multirow{2}{*}{ Göstergeler } & \multicolumn{4}{|c|}{2019} \\
\cline { 2 - 5 } & \multirow{2}{*}{ Toplam } & \multicolumn{3}{|c|}{ Dahil olmak üzere } \\
\cline { 2 - 5 } & & \multicolumn{1}{|c|}{ Mikro } & \multicolumn{1}{|c|}{ Küçük } & \multicolumn{1}{|c|}{ Ortalama } \\
\hline Katma değer (milyon manat) & 11071,7 & 4900,8 & 1423,2 & 4747,7 \\
\hline Çalışan sayısı, bin kişi & 332,2 & 40,2 & 85,1 & 206,9 \\
\hline $\begin{array}{l}\text { Ortalama aylık nominal maaş, } \\
\text { manat }\end{array}$ & 531,0 & 332,5 & 437,0 & 624,6 \\
\hline $\begin{array}{l}\text { Sabit sermaye yatırımları, } \\
\text { milyon manat }\end{array}$ & 3422,2 & 515,5 & 494,2 & 2412,5 \\
\hline Üretim çıktısı, milyon manat & 19386,7 & 7523,8 & 2553,8 & 9309,1 \\
\hline
\end{tabular}

Tablodan da görülebileceği gibi 2019 y1lında yeni yaratılan katma değer 11071,7 milyon manat olup, bunun büyük kısmı mikro (\%44) ve orta ölçekli (\%43) işletmelere düşüyor. Sabit varlıklara yapılan yatırımların yaklaşık \% 70'i orta ölçekli işletmelere düştü. Bütün bunlara göre çıktının ana kısmı mikro ve orta ölçekli işletmelerin payına düşüyor ki, bu da mikro işletmelerin daha esnek olduğunu ve pazara daha hızlı adapte olduğunu gösteriyor.

İşletme varlıklarının mülk türlerine göre faaliyet gösteren mikro, küçük ve orta ölçekli işletmelerin sayısına ilişkin göstergelere dikkat edelim:

Tablo 2. Mülk türüne göre faaliyet gösteren mikro, küçük ve orta ölçekli işletmelerin sayısı

\begin{tabular}{|l|c|c|c|}
\hline \multirow{2}{*}{ Göstergeler } & \multicolumn{3}{|c|}{2019} \\
\cline { 2 - 4 } & Mikro & Küçük & Ortalama \\
\hline $\begin{array}{l}\text { Ekonomik faaliyet } \\
\text { türüne göre toplam: }\end{array}$ & 262622 & 5956 & 2726 \\
\hline dahil olmak üzere & \multicolumn{2}{|c|}{} \\
\hline Kamu malı & 744 & 440 & 600 \\
\hline Devlet diş1 mülkiyet & 261878 & 5516 & 2126 \\
\hline Kişiye ait mülk & 259694 & 4948 & 235 \\
\hline Yabancı mülk & 1739 & 402 & 99 \\
\hline Ortak mülkiyet & 445 & 166 & 2792 \\
\hline
\end{tabular}


İktisadi faaliyet türünde mikro varlıkların payı da büyüktür. Devlet mülkiyetinin toplam mülk içindeki payı çok düşüktür. Sırasıyla, mikro $-\% 0,28$, küçük $-\% 7$, orta $\% 22$, bu da piyasa ekonomisi sisteminin özelliklerini yansıtır.

Tablo 3. Faaliyette olan mikro, küçük ve orta ölçekli işletmelerin sayısı

\begin{tabular}{|l|l|l|l|}
\hline \multirow{2}{*}{ Göstergeler } & \multirow{2}{*}{ Toplam } & \multicolumn{2}{|c|}{2019} \\
\cline { 3 - 4 } & & \multicolumn{2}{|c|}{ dahil olmak üzere } \\
\cline { 3 - 4 } & & 31196 & 240108 \\
\hline $\begin{array}{l}\text { Toplam ticari varlık } \\
\text { sayıs1 }\end{array}$ & 271304 & 22514 & 24018 \\
\hline $\begin{array}{l}\text { Mikro işletme } \\
\text { varlıklarının sayıs1 }\end{array}$ & 262622 & & - \\
\hline Küçük işletme sayıs1 & 5956 & 5956 & - \\
\hline $\begin{array}{l}\text { Orta ölçekli } \\
\text { işletmelerin sayısı }\end{array}$ & 2726 & 2726 & \\
\hline
\end{tabular}

Faaliyette olan işletmelerin çoğunluğu -\%89 - bireysel girişimcilerdir, bu da bireysel girişimciliğin yaratılmasının ve tescilinin son derece basit olduğunu göstermektedir. 
Tablo 4. Yeni oluşturulan ve tasfiye edilen mikro, küçük ve orta ölçekli işletmelerin sayısı

\begin{tabular}{|c|c|c|c|c|c|c|c|}
\hline \multirow[t]{3}{*}{ Göstergeler } & \multirow{3}{*}{ Toplam } & & 019 & \multirow{3}{*}{ Göstergeler } & \multirow{3}{*}{ toplam } & & \\
\hline & & \multicolumn{2}{|c|}{ dahil olmak üzere } & & & \multicolumn{2}{|c|}{ dahil olmak üzere } \\
\hline & & $\begin{array}{l}\text { Yasal } \\
\text { kişiler }\end{array}$ & $\begin{array}{l}\text { Bireysel } \\
\text { girişimciler }\end{array}$ & & & $\begin{array}{c}\text { Yasal } \\
\text { kişiler }\end{array}$ & $\begin{array}{c}\text { Bireysel } \\
\text { girişimci } \\
\text { ler }\end{array}$ \\
\hline 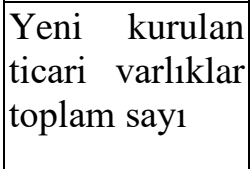 & 103949 & 15961 & 87988 & $\begin{array}{l}\text { Tasfiye edilmiş } \\
\text { ticari kuruluşlar } \\
\text { toplam sayı }\end{array}$ & 30483 & 454 & 30029 \\
\hline $\begin{array}{l}\text { Yeni yaratılmış } \\
\text { mikro işletme } \\
\text { varlıklarının } \\
\text { sayısı }\end{array}$ & 103756 & 15768 & 87988 & $\begin{array}{l}\text { Tasfiye edilen } \\
\text { mikro işletme } \\
\text { varliklarının } \\
\text { sayısı }\end{array}$ & 30457 & 428 & 30029 \\
\hline \begin{tabular}{|lc} 
Yeni & kurulan \\
küçük & işletme \\
sayis1 &
\end{tabular} & 161 & 161 & - & $\begin{array}{l}\text { Tasfiye edilen } \\
\text { küçük işletme } \\
\text { sayısı }\end{array}$ & 17 & 17 & - \\
\hline 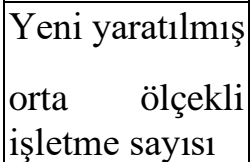 & 32 & 32 & - & $\begin{array}{l}\text { Tasfiye edilen } \\
\text { orta ölçekli } \\
\text { işletme sayısı }\end{array}$ & 9 & 9 & - \\
\hline
\end{tabular}

2019 'da yeni oluşturulan ve tasfiye edilen işletmelerin dinamikleri de cesaret vericidir. Böylece, yeni oluşturulan varlıkların sayısı, tasfiye edilenlerin sayısını 3 kattan fazla aşıyor. Bu dinamik, tüm konular için yaklaşık olarak aynıdır.

2019 yılında ülkede çalışan yabancı sayısı mikro işletmelerde 349, küçük ve orta ölçekli işletmelerde sirasiyla 692 ve 1589 oldu.

Ancak bugün Azerbaycan'da girişimcilik alanında hala sorunlar var. Mikro, küçük ve orta ölçekli işletmelerin geliştirilmesi, ekonomik çeşitlendirme, rekabet gücünün artırılması ve istihdam açısından özel bir öneme sahiptir. Dolayısıyla küçük ve orta ölçekli işletmelerin Gayri Safi Yurtiçi Hasıla (GSYIH) içindeki payına ve gelişmiş ülkelerdeki istihdama bakarsak, Mikro, Küçük, Orta Ölçekli Girişimcilik (MKOS) ekonominin ana itici gücü olduğunu görebiliriz.

Avrupa ülkelerinde, tüm işletmelerin $\% 93$ 'ünün 10 'dan az çalışanı vardır. Toplam çalışanların \%67'si mikro, küçük ve orta ölçekli işletmelerde çalışmakta ve toplam katma değerin \%58'ini oluşturmaktadır. Bazı vergi teşviklerinin oluşturulması, yatırımların teşviki için kriterlerin önemli faktörlerden biri olduğu unutulmamalıdır.

Özel sektörün rolünü artırmak, girişimciliği geliştirmek, ekonomi, istihdam, gölge ekonomiyi azaltmak için Vergi Kanununda önemli değişiklikler yapıldı ve bu değişikliklere göre 1 Ocak 2019'dan itibaren küçük ve orta ölçekli işletmeler için indirimler sağlandı.

-Küçük ve orta ölçekli işletme kategorisine ait şirketler, küçük ve orta ölçekli işletme siciline kayıt tarihinden itibaren 7 yıl süreyle kar, arsa ve katma değer vergisinden muaftır. 
-Küçük işletmeler için indirimler, girişimcilik faaliyetlerinden elde edilen gelirin ve kârın $\% 75$ 'inin vergi muafiyetini içerir.

-Mikro Küçük ve Orta Ölçekli İşletmeler emlak vergisinden vb. muaftır.

Sonuç olarak, "gölge ekonomi" 1995'de \%60, 2015'te \%42 ve 2019'da sadece \%10'du. Bu, aşağıdaki diyagramda görülebilir:

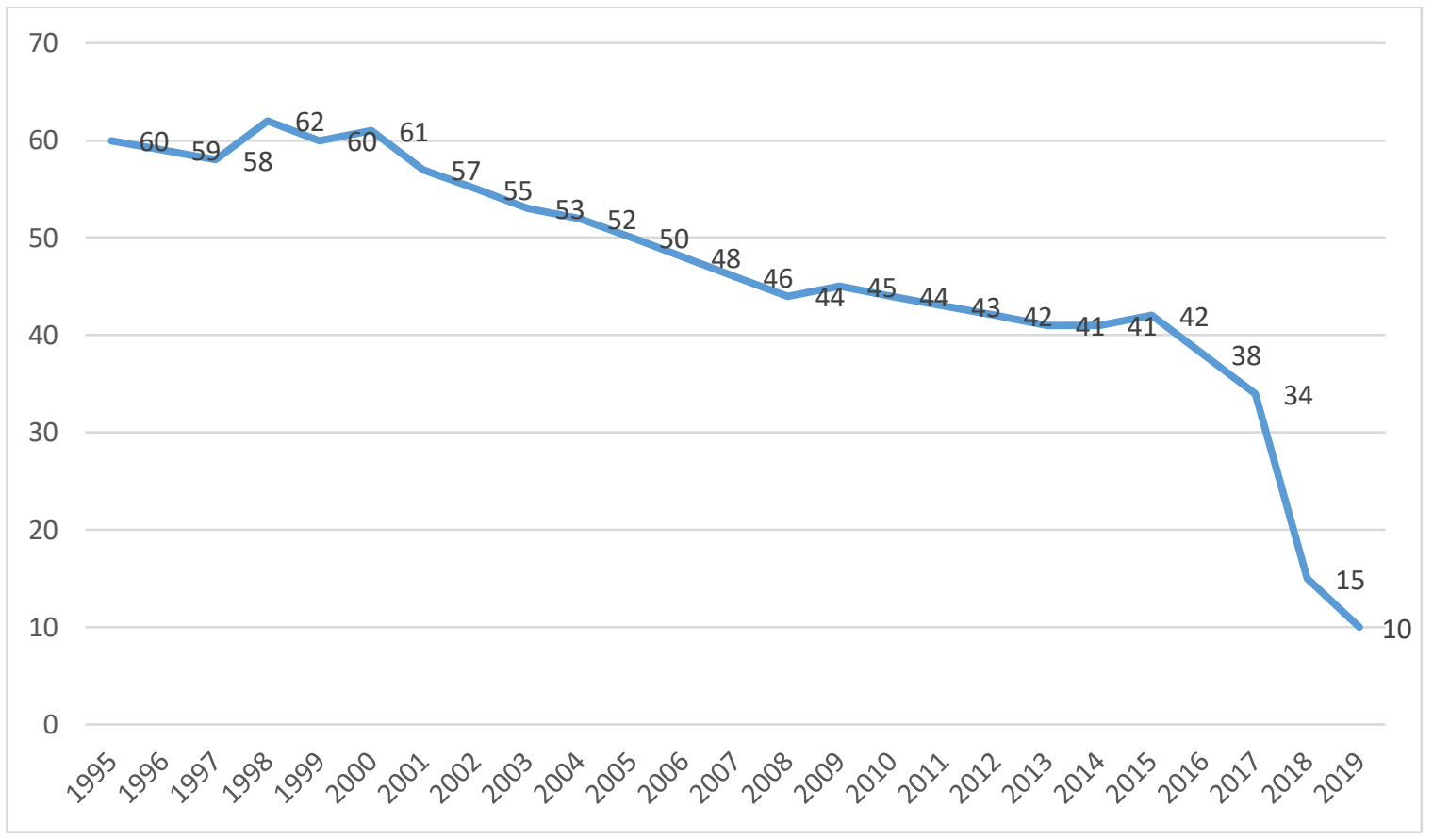

\section{SONUÇ VE ÖNERILER}

Ülkede girişimciliğin gelişmesi için öncelikle makroekonomik düzeyde sağlanan istikrarın hayata geçirilmesi ve girişimciliğe elverişli koşulların yaratılması gerektiğini dünya tecrübesinden biliyoruz. Dolayısıyla, elverişli bir ortamın yaratılması, devlet düzeyinden herkese, girişimcilik alanındaki her soruna bağlıdır.

Azerbaycan Cumhuriyetinde siyasi, sosyal ve ekonomik alanda ilk düşüşün girişimcilik faaliyetinin oluşumunu olumsuz etkilemesine rağmen ilerleyen dönemlerde bu alanlarda istikrarın sağlanmasının girişimciliğin gelişmesine önemli katkılar sağladığı söylenebilir ve çevreyi daha da iyileştirmekte yardımcı oldu.

Çalışmanın sonuçları:

1. Her şeyden önce, bunun küçük ve orta ölçekli işletmelerin gelişmesinin ülke ekonomisi üzerinde olumlu bir etkiye sahip olduğu gerçeğini içerdiği unutulmamalıdır. Çünkü bu tür işletmelerin sayısı artarsa, istihdam edilenlerin sayısı artacak ve başka ülkelere iş aramak için giden yerli halkın sayısı da azalacaktır.

2. Sonuç, Azerbaycan pazarında yerel olarak üretilen malların hacmi ile ilgilidir. Yani ülkedeki Küçük ve Orta Ölçekli Girişimci sayısı artarsa pazardaki kendi ürünlerimizin hacmi de artacaktır. Ayrıca bu işletmelerin mali güvencesi yüksek ise, kullanılan hammaddeler de yüksek kalitede 
olacaktır. Sonuç olarak, kalite açısından, bitmiş ürün kalite açısından yabancı malların gerisinde kalmıyor ve nüfus zaten yerel üretimle ilgili malları tercih ediyor.

3. Franchising dünya çapında birçok büyük şirkette ve gelişmiş ülkede kullanılmaktadır. Ancak bu yöntem, ülkemizde faaliyet gösteren küçük ve orta ölçekli şirketler için neredeyse bir finansman kaynağı olarak kullanılmamaktadır. Bunun için öncelikle büyük işletmelerin deneyimlerini kullanmak gerekiyor. Bir girişimci bu uygulamalardan yararlanmalı ve işine uygulamalıdır. Ayrıca küçük ve orta ölçekli işletmeler, franchise veren büyük firmaların markasını ve güvenini kullanarak bu yöntemi kullanarak pazarda belirli bir konum elde edebilirler.

4. Diğer bir öneri ise kitle fonlaması (crowdfunding) adı verilen bir finansman yöntemi kullanmaktır. Dolayısıyla Azerbaycan'da olmayan bu yöntem aslında içinde yaşadığımız internet çağında mükemmel bir araçtır. Bu doğrultuda bir internet platformu oluştururlarsa, iş ortamına yeni bir adım atmaya başlayan her şirket, sosyal tanıtımıyla yatırımcıların ilgisini çekebileceği gibi, farklı ülkelerden de fon çekebilir. Öyle bile olsa, birine sahip olmak, ortalama bir insanın ulaşamayacağı bir şeydir.

5. Bir sonraki teklif, küçük ve orta ölçekli işletmelerde mali riskleri önlemek veya azaltmaktır. Böylelikle, uluslararası uygulamada ve büyük şirketler tarafindan hala yaygın olarak kullanılan bir riskten korunma taktiği kullanılırsa, girişimci riskleri önceden tahmin edebilir veya riske maruz kalırsa bu durumdan minimum hasarla kurtulabilir. Bunu yapmak için, bu faaliyete dahil olan uzmanların deneyimlerini kullanmak gerekir.

6. Girişimcilikteki bir diğer eksiklik de sigortayla ilgilidir. Bu nedenle, şu anda sigorta şirketleri küçük ve orta ölçekli işletmeleri sigortalamakla pek ilgilenmiyor. Çünkü bu tür ortaklarla ilişkili riskleri hesaplayamazlar ve sonuç olarak sigorta yükümlülügü üstlenmezler. Bunu önlemek için bir takım yasal düzenlemeler hazırlanır ve her iki tarafın yararına bir takım kararlar alınırsa, sigorta şirketleri de finansman konusunda devlet desteği alırsa bu sorun çözülebilir.

7. Bölgelerde girişimciliğin gelişmesi her zaman devletin odağında ve bu alanda önemli çalışmalar yapılıyor. Ancak tüm bunlara rağmen bu alanda sorunlar var ve aşılması gerekenler şunlar: öncelikle bölgelerin yetkili temsilcilerinin katılımıyla girişimcilerle toplantılar yapılmalıdır, girişimciler öncelikle bölgelerde küçük ve orta ölçekli işletmeler geliştirme özgürlüğüne sahip olmalıdır, kararların gecikmeden uygulanması, ekonomik faaliyette bulunanlar için düşük üretim ve yönetim maliyetleri, girişimcinin kendi fikir ve düşüncelerinin özgürce uygulanması ,yeni başlayanlar için düşük başlangıç sermayesi ihtiyacı, girişimcilerin faaliyetlerini tüketicilerin ihtiyaçları doğrultusunda inşa etmeleri ve gerekirse ürünün şeklini ve kalitesini kısa sürede değiştirebilmesi, küçük ve orta ölçekli işletmelerin gelişimini artırmak için tercihli vergilerin getirilmesi, gümrükleme işlemlerinin kısaltılması, gümrük vergilerinin uygulanmasında indirimlerin artırılması, iş dünyasında elverişli bir rekabet ortamının oluşmasını sağlayan "Rekabet Yasası" nın benimsenmesine yönelik prosedürünün hızlandırması. 


\section{KAYNAKÇA}

Azerbaycan Cumhuriyeti Anayasas1. 27.11.95 il

Azerbaycan Cumhuriyeti "Girişimcilik Faaliyetleri" Kanunu 15.12.1992, № 405

Azerbaycan Cumhuriyeti'nde Küçük Ve Orta Ölçekli Işletmeler Düzeyinde Tüketim Malları Üretimi Için Stratejik Yol Haritası, 6 Aralık 2016.

“Bölgelerin Sosyo-Ekonomik Kalkınması” Devlet Programı, (2004-2008). 11.02.2004, № 24

“Bölgelerin sosyo-ekonomik kalkınması” Devlet programı, (2009-2013). 14.04.2009, № 80

“Bölgelerin sosyo-ekonomik kalkınması” Devlet programı, (2014-2018). 27.02.2004, № 118

“Bölgelerin sosyo-ekonomik kalkınması” Devlet Programı, (2019-2023). 29.01.2019, № 500

Abbasov, A. (1998). Girişimcilik Etkinliği; Oluşum Türleri ve Gelişme Sorunları. Bakü: Bilim Yayınevi.

Abbasov, A. (2011). İşletmenin Organizasyonu ve Yönetimi. Bakü: Ekonomi Üniversitesi Yayınevi.

Ganjiyev, Ch., Novruzov, N., Mammadov, M. (1999). Girişimciliğin Temelleri. Bakü: Zaman Yayınevi.

Haciyev, J., Ahadov, V. (2021). Azerbaycan'da Pandemi Koşullarında Ticari Kuruluşlara Devlet Desteğinin Öncelikli Yönleri, Bakü Bilimsel Eserler Dergisi, Azerbaycan İnşaat ve Mimarlık Üniversitesi, 152-158.

Hacıyev, C., Ahadov, V. (2020). Azerbaycan, Bakü Ulaşım Kompleksinde Girişimciliğin Gelişiminin Kurumsal Yönleri. Uluslararası Azerbaycan-Ukrayna Bilimsel-Pratik Konferans1, 367-370.

Hacıyev, C., Ahadov, V (2021). Azerbaycan'da Girişimciliğin Gelişmesinde Kurumsal Düzenlemenin Rolünün Artırılması. Moskova: Tüm Rusya'nın Bilimsel ve Analitik Dergisi "Financial Economics", 205-211.

Hajiyev, C. (2021). The Actual Problems of Entrepreneurship Development in the Transport Sector of Azerbaijan. Baku: International Scientific Journal of Economics and Entrepreneurship, 654-658.

İbrahimov, İ. (2005). Girişimcilik Oluşumunun Sorunları. Bakü: Elm Yayınevi.

Ganbarli, A. (2000). Azerbaycan'da Girişimciliğin Gelişmesinin Sorunları ve Çözümleri. Monograph Baku.

Manafov, Q. (2011). Girişimcilik Teorisi. Bakü: Chashyoğlu Yayınevi.

Niftullayev, N. (2002). Girişimciliğin Temelleri. Bakü: Zaman Yayınevi.

Samadzade, Z. (2001). Dünya Ekonomisi Çin'in Ekonomik Mucizesi. Bakü: Bilim Yayınevi.

Hosking, A. (2000). Girişimcilik kursu. Bakü: Azerbaycan Ekonomi Üniversitesi Yayınevi.

Lapusta, M., Pornye, A., Starostin, Yu., Skamy, L. (2002). Girişimcilik. Moskova: Tsifra Yayınevi. 